Karstenia 40: 159-166, 2000

\title{
Ultrastructure of Barbeyella minutissima (Myxomycetes)
}

\author{
MARTIN SCHNITTLER, STEVEN L. STEPHENSON and YURI K. NOVOZHILOV
}

SCHNITTLER, M., STEPHENSON, S.L., \& NOVOZHILOV, Y.K. 2000: Ultrastructure of Barbeyella minutissima (Myxomycetes). - Karstenia 40: 159-166. Helsinki. ISSN 0453-3402.

\begin{abstract}
The minute myxomycete Barbeyella minutissima Meyl. was studied with scanning electron microscopy. Comparison of the morphological features of Barbeyella minutissima with those of Echinostelium arboreum H.W. Keller \& T.E. Brooks provides evidence for a systematic position close to the genus Echinostelium. Observation of developing sporocarps under dissecting as well as compound microscopes indicated an epihypothallic pattern of development, which suggests a systematic position for B. minutissima that is intermediate between the Echinosteliales and the Stemonitales.
\end{abstract}

Key words: Myxomycetes, Barbeyella minutissima, morphology, scanning electron microscopy, sporocarp development.

Martin Schnittler and Steven L. Stephenson, Department of Biology, Fairmont State College, Fairmont, West Virginia 26554-2470, U.S.A.

Yuri K. Novozhilov, V.L. Komarov Botanical Institute of the Russian Academy of Sciences, 197376 St. Petersburg, Russia

\section{Introduction}

The minute myxomycete Barbeyella minutissi$m a$, described by Meylan (1914) from the Swiss Jura, forms a monotypic genus with an uncertain position within the taxonomic system of the Myxomycetes (Alexopoulos \& Brooks 1971). Only known from about 60 collections and fewer than 30 localities world-wide, B. minutissima was long thought to be exceedingly rare. However, within a study of its microhabitat requirements (Schnittler, Stephenson \& Novozhilov 2000) the species was found in two localities with abundant fructifications. One locality is situated in the Appalachians in eastern North America (Stephenson 1983), and the other in the German Alps (Schnittler \& Novozhilov 1998).

The goal of the present paper is to describe the ultrastructure of the sporocarps of Barbeyella minutissima, report our observations relating to sporocarp development, and discuss possible systematic relationships of Barbeyella with other myxomycete genera.

\section{Materials and methods}

During a two-week long investigation in the Northern Ammergauer Alps, Bavaria, fresh sporocarps of $B$. minutissima were observed by means of magnifying $(3 \times)$ glasses in the field and frequently collected. For the developmental observations, material from eastern North America (Blister Run in West Virginia, see below) was used. Ultrastructural investigations were carried out with material from three localities, one in the European Alps and two in the Appalachians. For comparison of morphological structures, material from Echinostelium arboreum H.W. Keller \& T.E. Brooks (1976) collected in Kazakhstan was used.

Sporocarps from air-dried specimens collected in the field were studied with a JEOL $35 \mathrm{c}$ scanning electron microscope at the Komarov Botanical Institute in St. Petersburg. Air-dried sporocarps were mounted on copper stubs using a double-sided sticky film and sputtercoated with gold up to 200-500 $\AA$ thickness. Cross- 

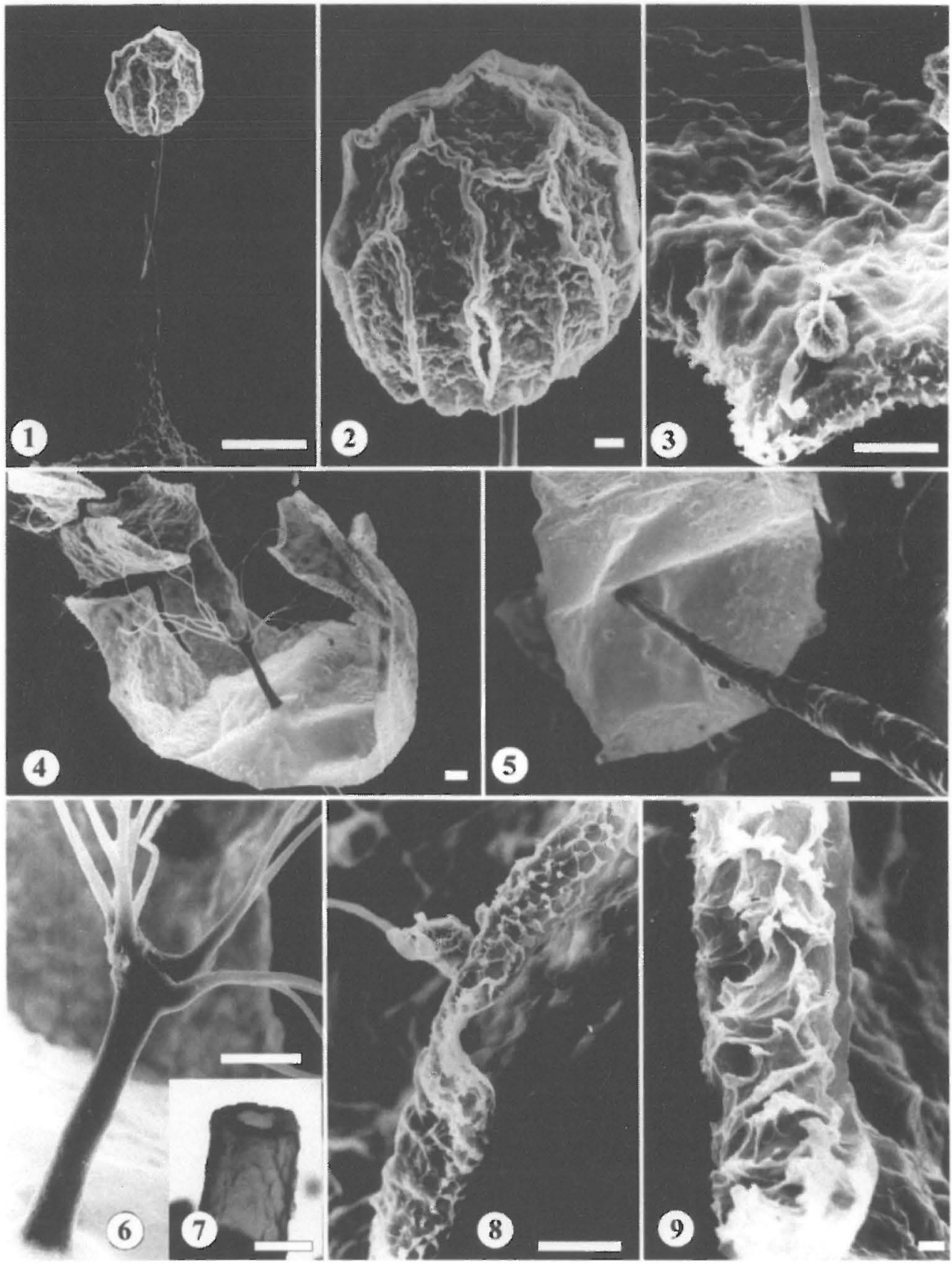

Figs. 1-9. SEM micrographs of Barbeyella minutissima from the German Alps, Bavaria (Schnittler 5404). - 1: Habit of an entire sporocarp. Bar $=100 \mu \mathrm{m} .2$ : Sporotheca with the plates of the peridium breaking along pre-formed ridges. One large and several small holes are visible on the dehiscence lines. Bar $=10 \mu \mathrm{m} .3$ : Detail of a peridial plate with an attached thread of the capillitium. Bar $=10 \mu \mathrm{m}$. 4: Sporocarp after spore dispersal; plates of the capillitium are attached to the threads of the capillitium. Bar $=10 \mu \mathrm{m}$. 5: Upper part of the stalk. Bar $=10 \mu \mathrm{m}$. 6: Uppermost part of the stalk forming a columella after extending through the peridium, then branching abruptly into the capillitial threads. Bar $=10 \mu \mathrm{m} .7$ (Inset): Detail of a broken, hollow capillitial thread. Bar $=1 \mu \mathrm{m}$. 8: Margin of the peridium. Wart-like processes are connected by a network of small ridges form an opening mechanism along the margin of the capillitium plates, thus working like a zipper. Bar $=10 \mu \mathrm{m}$. 9: Detailed view of processes along the margin of a peridial plate. $\mathrm{Bar}=1 \mu \mathrm{m}$. 
sections through stalks were cut with a razor blade. Morphological terms used for descriptions of sporocarps are those found in Lado and Pando (1997). With a few exceptions for which references are given, names of myxomycete species mentioned herein follow Martin and Alexopoulos (1969).

Specimens examined: Barbeyella minutissima: Germany. Bavaria, Karwendelgebirge, Garmisch- Partenkirchen: decorticated logs of Picea, moist wood covered with a thin layer of mosses and algae, in a narrow, deep left side valley of the 'Partnachklamm', spruce-fir woodland ca. $800 \mathrm{~m} \mathrm{SSE}$ of the 'Kochelberg-Alm', 1050 $\pm 20 \mathrm{~m}, 4^{\circ} 31^{\prime} 55^{\prime \prime} \mathrm{N} 10^{\circ} 24^{\prime} 20^{\prime \prime} \mathrm{E} \pm 3 \mathrm{~km}, 18$.24.X.1994 Schnittler 5367, 5388, 5359, 5404, 5435, 5442, 5447 (JE, Schnittler \& Novozhilov 1998). U.S.A. West Virginia, Randolph Co., Appalachian Mts.: Blister Run, $1100 \pm 50 \mathrm{~m}, 38^{\circ} 51^{\prime} \mathrm{N} 79^{\circ} 45^{\prime} \mathrm{W} \pm 5 \mathrm{~km}$, 26.X.1993 Stephenson 2299, 3936; 23.VII.1997 Stephenson 9042 (all FWVA, Stephenson 1983); 4.X.1997 Schnittler 11287, 11295. North Carolina, Swain Co., Great Smoky Mountains National Park: Mt.

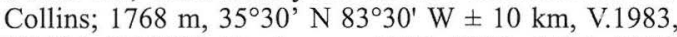
V.1984, IX.1985 Stephenson 1557, 2399, 2404, 3336, $3587,3620,3634,3635,3645,3649,3662,3663$, $3668,3679,3680,3682,3684,3686-3688$ (FWVA, Stephenson 1983).

Echinostelium arboreum: Kazakhstan. Mangyschlak Peninsula: Aktau; obtained in moist chamber culture from the bark of Salsola arbuscula Pall., stony ground over limestone, near the upper edge of a cliff ca. $1 \mathrm{~km} \mathrm{NW}$ of the well Sauttuy at the eastern margin of the depression Karagije, $110 \mathrm{~m}, 51^{\circ} 52^{\prime} 37^{\prime \prime} \mathrm{N}$ 4331'23" E \pm 1 km, 30.IV.1995 Schnittler 6809 (JE).

\section{Results}

Barbeyella minutissima is a very distinctive myxomycete; the species can be identified easily by the tiny, black and long-stalked sporocarps. Since taxonomic descriptions based on observations with the light microscope were given by Kowalski and Hinchee (1972) and Lakhanpal and Mukerji (1976), we mention herein only features revealed from observations with the scanning electron microscope (SEM).

The globose sporotheca is attached to a long, slender and tapering stalk (Fig. 1). Alexopoulos (1969) reported the stalk as stuffed with granular deposits, whereas Kowalski and Hinchee (1972) described it as hollow. We found in several sporocarps examined by SEM the stalk base to be solid and stuffed with granular material except for a few bubble-like holes that may be remnants of the stalk cavity. However, the capillitium was always observed as hollow (Fig. 7). The upper half of the stalk tapers to a diameter of less than $10 \mu \mathrm{m}$ at the base of the sporotheca (Figs. 2, 5) and continues inside the sporotheca as a columella, which abruptly merges into a few main capillitial branches (Figs. 4, 6, 12). The globose to slightly prolonged sporotheca has a wrinkled, cartilaginous peridium. As it is the case for several species of Licea, the peridium dehisces into lobes along pre-formed lines (Figs. 2, 13). The lower, prolonged lobes are connected with the stalk, giving rise to an irregularly stellate appearance for dehisced sporocarps. The upper lobes are rounded and connected to the capillitium only via funnel-like attachments. The inner surface of the peridium is more or less smooth, but each of the lobes is bordered by a band of irregular, wartlike processes (Figs. 8, 9). As observed in mature sporocarps under a dissecting microscope, drying leads to a shrinking of the peridial lobes; this causes tension, resulting in a zipper-like opening of these plates along the warted margin. The processes forming the zipper are up to $2 \mu \mathrm{m}$ high and often connected by small ridges to form an incomplete network (Fig. 9). Fresh spores, when observed under light microscope were found to be globose, but shrinking occurs as they become dry, such as when observed under the SEM (Fig. 14). This produces an angular appearance due to folding of the spore wall, which has a coarse network of ridges. The ornamentation consists of blunt warts up to $0.2 \mu \mathrm{m}$ high, seemingly formed by coalescing smaller warts.

Based on measurements of our specimens and those reported in literature descriptions (Kowalski \& Hinchee 1972, Lakhanpal \& Mukerji 1976, Härkönen 1989), Barbeyella seems to be somewhat variable in size, ranging from $0.2-0.4(-0.9)$ $\mathrm{mm}$ in height, but more or less constant in all other morphological features. A possible exception is a collection of three sporocarps from Oregon (Curtis 1968), reported as brighter in colour, with a more heavily branched capillitium and larger spores. In general, specimens from eastern North America seem to be slightly larger than those from most other localities where the species has been collected, and the capillitium is more frequently branched (Figs. 11, 12). Another remarkable feature is the presence of a hole in the centre of each peridial platelet, where the capillitium joins the latter. Such holes were visible in all three specimens from eastern North America observed by SEM (Fig. 10); they were less prominent in the German specimens (Figs. 2, 3).

The ultrastructure of Echinostelium arboreum H.W. Keller \& T.E. Brooks (1976) shows 
a number of similarities to that of Barbeyella. Both species have a true columella and a peridium at least during early stages of development, but two features differ. First, in Echinostelium arboreum the peridium opens with sutures instead of ridges (Fig. 20). Second, the capillitium of mature sporocarps has usually no connection to the peridium (Fig. 22), whereas it remains connected in Barbeyella. However, SEM micrographs provide evidence that in early stages of development the capillitium is connected with the peridium. Less prominent than in Barbeyella, small, funnel-like depressions can be seen also in Echinostelium arboreum. These are located near the centre of the peridial lobes (Fig. 20). Al- though not mentioned by the authors, Fig. 3 in the paper by Haskins and McGuiness (1989) describing the ultrastructure of $E$. arboreum also shows such depressions. The connections between peridium and capillitium usually vanish, but can be seen in an occasionally still connected peridial lobe (Figs. 23, 24). Another structural feature shared by Barbeyella minutissima and Echinostelium arboreum are the hollow threads of the outer capillitium (Figs. 7,21).

During the field investigations in the German Alps, we observed plasmodia of Barbeyella, which were first noted by Jarocki (1931). These plasmodia have the appearance of a protoplasmodium, about 1.5 times the size of the sporothe-

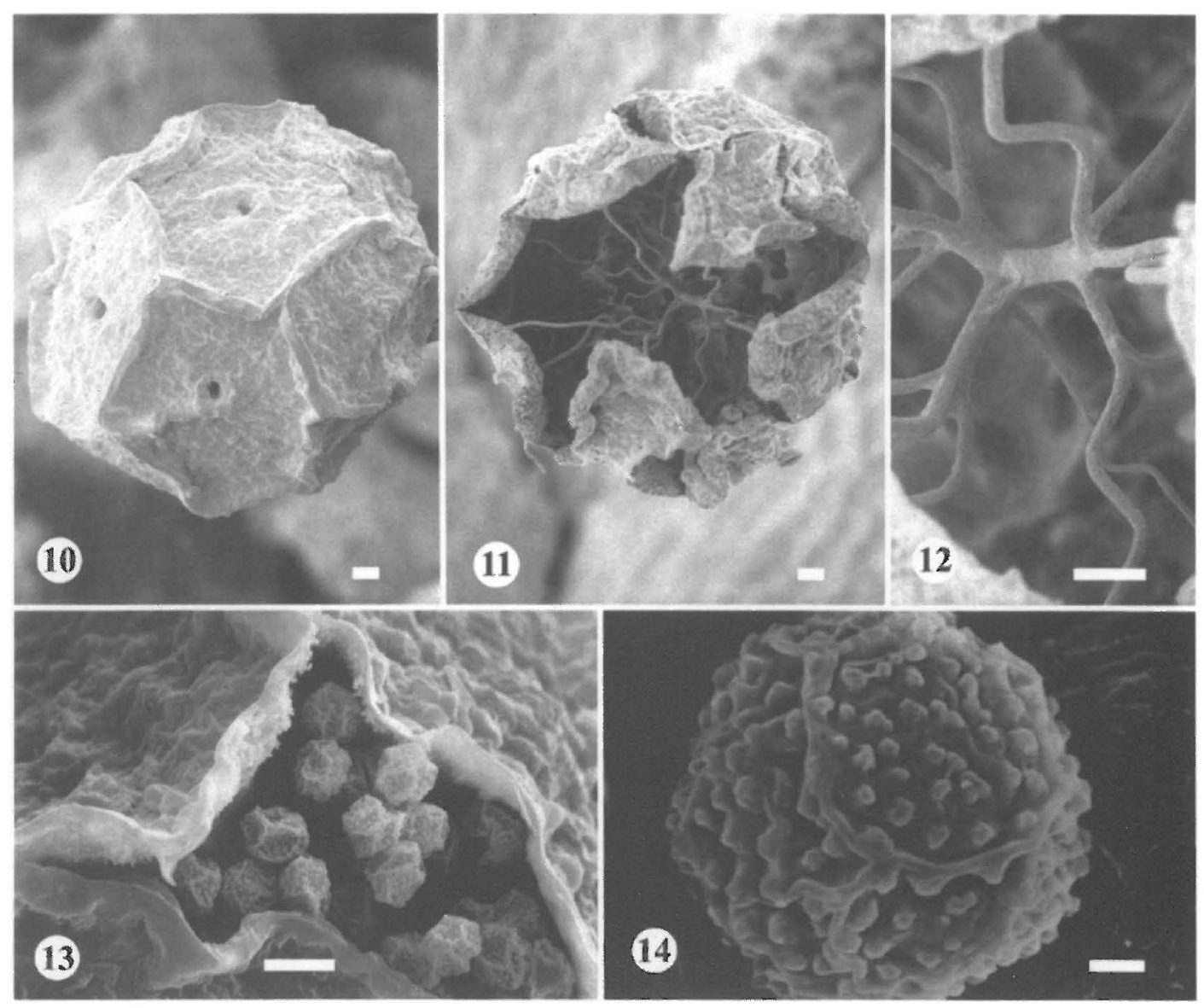

Figs. 10-14. Sporocarps of Barbeyella minutissima from the Great Smoky Mountains (Stephenson 3620), SEM micrographs. - 10: Still closed, slightly immature sporocarp showing holes in the centres of the peridial plates where the capillitial threads are attached. Bar $=10 \mu \mathrm{m} .11$ : Opened mature sporocarp. Bar $=10 \mu \mathrm{m} .12$ : Enlarged view of Fig. 11, with the columella tip branching into three main capillitial threads in the centre. Bar $=10 \mu \mathrm{m}$. 13: Dehisced peridium, with the spore mass exposed. Bar $=10 \mu \mathrm{m} .14$ : Spore with warts and a coarse network of ridges. Bar $=1 \mu \mathrm{m}$. 
ca in mature sporocarps, appearing firstly transparent, colourless and hemispherical, later becoming sprinkled with darker tints and finally turning milky throughout. Developing sporocarps appear always scattered and isolated and are never connected by plasmodial strands. Sporocarp development was observed on specimens from eastern North America (Appalachians, Blister Run). Three stages of development could be distinguished under a dissecting microscope $(100 \times)$, and several sporocarps were prepared as mounted slides (Figs. 15-19). First, a dark stalk initial forms inside the plasmodium. The remaining, milky plasmodial mass moves up the stalk, elongating it as a result. In this stage, the stalk is still shorter than in mature sporocarps, with a ball of entirely unstructured, translucent to milkywhite, shining protoplasm at the top (squashed mass in Fig. 15). In a second stage, when the stalk has reached its final length, elevating the sporotheca initial thereby, the capillitium and peridium are formed. The first step was not observed directly, but in Fig. 15 patches of granular deposits can be seen, which are probably the initials of

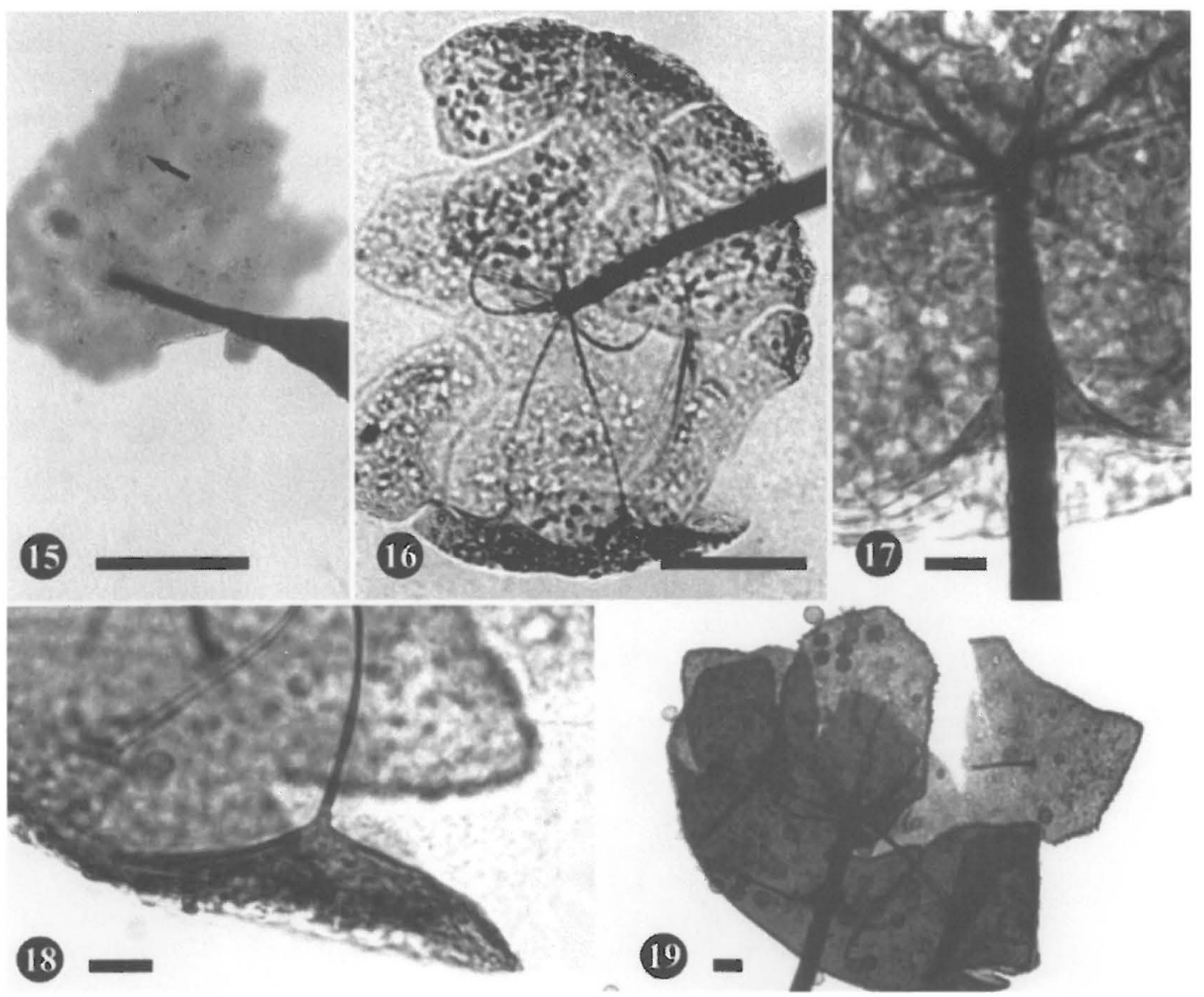

Figs. 15-19. Development of Barbeyella minutissima, mounted slides (polyphenyl lactophenol) as seen with the light microscope, Appalachian Mountains, Blister Run (Schnittler 10287). - 15: Squashed sporocarp at an early stage of development, with an already solid stalk but a still undifferentiated mass of protoplasm that later becomes the sporotheca. The granular fields (arrow) are the initials of the peridial plates. Bar $=100 \mu \mathrm{m}$. 16: Sporocarp with capillitium and peridium already fully developed but still having an colourless and undifferentiated mass of protoplasm inside. $B a r=50 \mu \mathrm{m}$. 17: Base of the sporotheca, showing the peridium with developing spores. Bar $=10 \mu \mathrm{m}$. Fig. 18: Funnel-like attachment of a capillitial threat to a peridial plate, side view. Bar $=10 \mu$ m. 19: Late developmental stage showing peridial plates with fully developed marginal processes. Bar $=10 \mu \mathrm{m}$. 
the peridial plates. The next developmental step captured shows capillitial threads arising from the tip of the columella, which are connected to the developing platelets of the peridium (Fig. 16). Funnel-like invaginations of the hollow capillitial threads let the peridium appear as an extention of the capillitium (Fig. 18). Where the edges of these funnel-like structures meet, the margins of the peridial platelets develop (Fig. 16). At this point, the plasmodial mass is still unstructured. In a third stage (the capillitium is already fully developed), the internal protoplasma mass begins to undergo spore cleavage. Spores are at first almost colourless and lack ornamentation (Fig. 17). Later, the zipper-like structures on the margins of the peridial platelets are formed. Simultaneously, peridial platelets become fully visible by thickening and intensive pigment synthesis (Fig. 19). The sporocarp colour changes from light brown to dull brown and finally black.

\section{Discussion}

The SEM micrographs of mature specimens of Barbeyella minutissima show a capillitium apparently growing as an extension of the columella, firmly connected to the stalk. These morphological features are similar to those found in the Stemonitales. Since members of this order of myxomycetes are the only myxomycetes characterised by sporocarps with an epihypothallic pattern of development, the question arises as to how the fructifications of Barbeyella develop. Unfortunately, due to its special microhabitat requirements, it is unlikely that Barbeyella will grow easily in culture. Up to now, the observations reported above, made of sporocarps from carefully collected, long stripes of wood from a decorticated $\log$, provide the only indications about the developmental pattern of the species. Several lines of evidence for an epihypothallic development, as reported by Ross (1973) for the Stemonitales, can be derived from our developmental and ultrastructural observations. First, an unstructured protoplasma mass lacking a firm peridium and elevated by the developing stalk was seen in the dissecting microscope. Second, the stalk of Barbeyella tapers into a true columella from which at least partly the capillitium derives (Fig. 6), as reported for Stemonitis virginiensis by Mims (1973). Third, the peridium is seemingly discontinuous to the stalk (Fig. 17), as indicated by the narrow angle between peridium and stalk at the base of the sporotheca. Again this is a stemonitaceous feature (Ross 1957, 1973).

Based on its overall habit, Barbeyella was first thought to be related to Lamproderma, and until publication of the monograph of Martin and Alexopoulos (1969), it was considered to belong to the family Stemonitaceae. Alexopoulos and Brooks (1971), who reviewed the taxonomic history of the species in detail, erected the new family Clastodermaceae and included Barbeyella and Clastoderma in the order Echinosteliales. Their main reasons were the occurrence of a protoplasmodium and the subhypothallic type of development assumed for Barbeyella. Kowalski and Hinchee (1972) also suggested a close relationship with Clastoderma, the second genus of the Clastodermaceae. They mentioned three main characters shared by both genera: again, the protoplasmodium which was demonstrated for Clastoderma debaryanum by McManus (1961), the hollow stalk stuffed with refuse matter at the base, and a capillitium firmly attached to the peridium. More recently, Frederick et al. (1986), while undertaking an SEM-based study of Clastoderma debaryanum, found strong evidence that the peridial platelets at the end of the capillitial threads are not of peridial origin. These results were confirmed by Eliasson and Keller (1996). The only true peridium seems to be the collar at the base of the sporotheca, a character also found in some species of Echinostelium. This observation makes the third of the three characters shared by Barbeyella and Clastoder$m a$ obsolete, and it would appear that the latter genus is more similar to Echinostelium.

The paper on the ultrastructure of $E$. arboreum by Haskins and McGuiness (1989), as well as the SEM photographs presented herein reveal a number of structural similarities between Barbeyella minutissima and Echinostelium arboreum. Common features like a peridium connected to the capillitium by funnel-shaped invaginations at least in early stages of development, hollow capillitial threads, and a stalk extending into the sporotheca as a true columella make a similar type of sporocarp development in both species likely. At least Echinostelium species with a stalk continuing into a true columella and a collar around the base of the sporotheca would seem to develop in an epihypothallic man- 
ner. Haskins (1978) provided evidence for this type of development by demonstrating the progressive elevation of the sporotheca initial from the substratum by the growth of the stalk, very similar to our observations in Barbeyella. Tracing this line of thought - epihypothallic development with a true columella and a collar - further, the logical continuation would be towards the Stemonitales, first with the genera Lamproderma and Macbrideola, both including species with a persistent peridium similar to that found in Barbeyella. Indeed, in Macbrideola scintillans the peridium is attached to a few, stout capillitial branches just like in Barbeyella (in small sporocarps, the capillitium does not branch and the peridium is attached directly to the end of the columella that extends through the whole sporotheca). In Enerthenema, this funnel-like connection of the columella tip to the peridium remnants, which is present even in mature specimens as a disk around the tip, is a diagnostic character for the genus. Funnel-like ends of capillitial threads that are connected to the peridium also occur in Lamproderma atrosporum, a nivicolous species with a more or less persistent peridium.
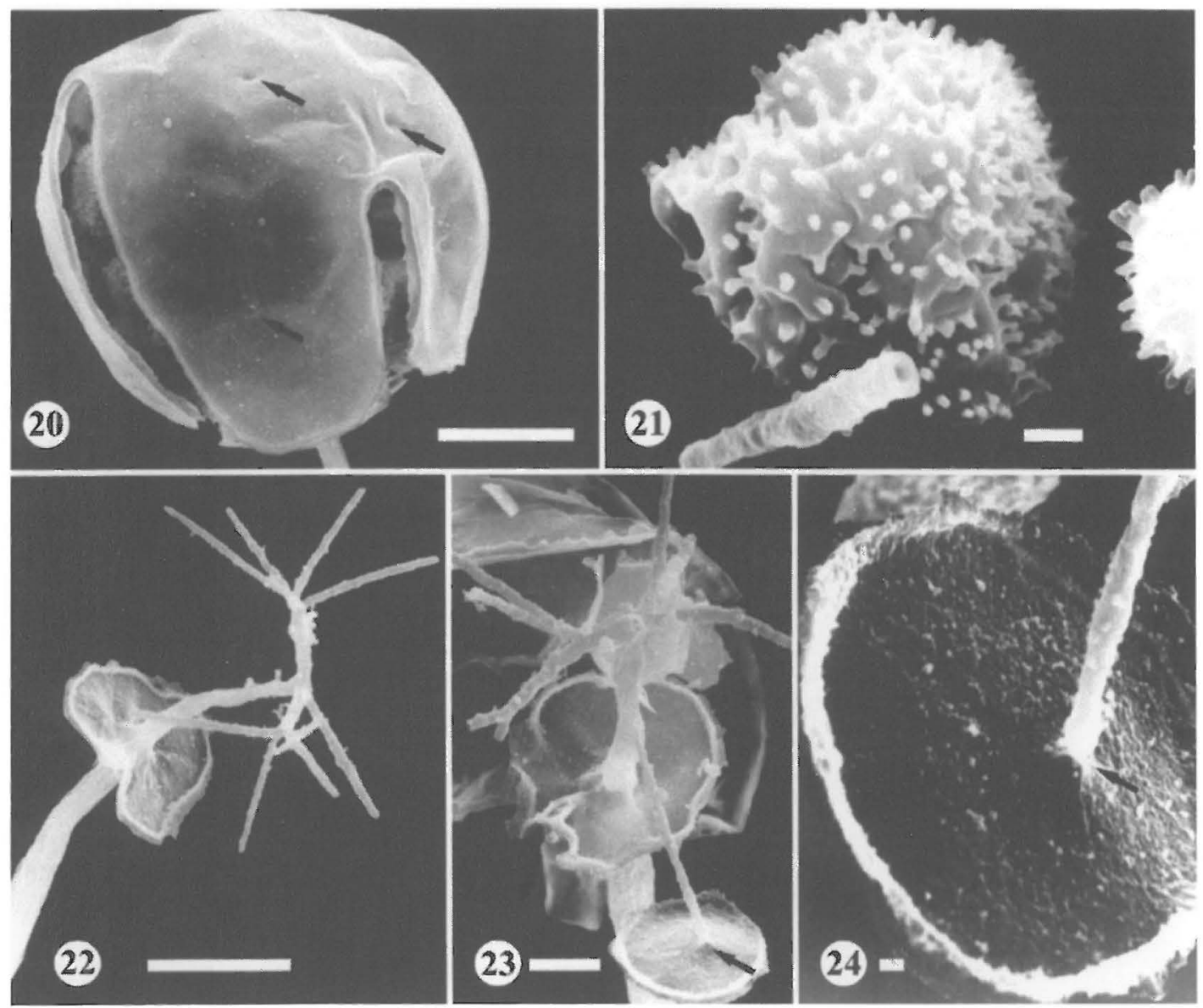

Figs. 20-24. SEM micrographs of Echinostelium arboreum, Kazakhstan, Mangyschlak Peninsula (Schnittler 6809). - 20: Sporocarp in development, with a still attached peridium opening along pre-formed sutures. Small, funnel-like depressions mark the attachment sites of capillitial threads (arrows). Bar $=10 \mu \mathrm{m}$. 21: Spore with a hollow, broken capillitial thread. Bar $=1 \mu \mathrm{m} .22$ : Mature, empty sporocarp with a basal peridial collar and free-ending capillitium. Bar $=10 \mu \mathrm{m}$. 23: In mature sporocarps the peridium falls away, but occasionally a piece of the peridium (arrow) remains connected to a capillitial thread. Bar $=5 \mu \mathrm{m}$. 24: Enlargement of Fig. 23, showing a capillitial thread with a constricted attachment site to the peridium (arrow), probably the designated breaking point. Bar $=1 \mu \mathrm{m}$. 
It may be possible that a phylogenetic line leads from species of Echinostelium with a well developed columella and a collar, such as $E$. $a r$ boreum, through forms like Barbeyella to members of the Stemonitales with a persistent peridium. Following this hypothesis, Barbeyella may represent a 'missing link' between the Echinosteliales and the Stemonitales, in the latter group perhaps closest to the genera Macbrideola or Lamproderma. Analysis of DNA sequences would be a highly desirable tool to reveal the true phylogenetic relationships of Barbeyella with other genera of myxomycetes.

Acknowledgements: Field work was supported by the German Academic Exchange Service (DAAD) for the third author, laboratory work by a further DAAD scholarship for the first author. We wish to express our thanks to L.A. Karzeva (Komarov Botanical Institute, St. Petersburg, Russia) for technical assistance during the SEM-investigations. For reviewing the text we are indebted to Dr. J. Landolt (Shepherd College, West Virginia) and Dr. E. Haskins (Washington State University). For helpful comments to the manuscript we wish to thank Dr. H.W. Keller (Missouri State University).

\section{References}

Alexopoulos, C.J. 1969: The experimental approach to the taxonomy of the myxomycetes. - Mycologia 61: 219-239.

Alexopoulos, C.J. \& Brooks, T.E. 1971: Taxonomic studies in the myxomycetes III. Clastodermaceae: a new family of the Echinosteliales. - Mycologia 63: 925-928.

Curtis, D.H. 1968: Barbeyella minutissima, a new record for the western hemisphere. - Mycologia 60: 708710 .

Eliasson, U. \& Keller, H.W. 1996: The genus Clastoderma: taxonomic evaluation and infraspecific variation of C. debaryanum. - Mycol. Res. 100: 601-609.

Frederick, L., Roth, I.L. \& Pendergrass, L. 1986: Observations on the "peridial platelets" of Clastoderma debaryanum. - Mycologia 78: 263-268.
Härkönen, M. 1989: Thirteen taxa of myxomycetes new to Finland. - Karstenia 28: 93-99.

Haskins, E.F. 1978: A reinvestigation of sporulation in the plasmodial slime mold Echinostelium minutum. Canadian J. Bot. 56: 1270-1273.

Haskins, E.F. \& McGuiness, M.D. 1989: Sporophore ultrastructure of Echinostelium arboreum. - Mycologia 81: $303-307$.

Jarocki, J. 1931: Mycetozoa from the Czarnohora mountains in the Polish Eastern Carpatians. - Bull. Acad. Pol. Sci. II 2: 447-464.

Keller, H.W. \& Brooks, T.E. 1976: Corticolous myxomycetes V: Observations on the genus Echinostelium. - Mycologia 68: 1204-1220.

Kowalski, D.T. \& Hinchee, A.A. 1972: Barbeyella minutissima: a common alpine myxomycete. - Syesis 5: 95-97.

Lado, C. \& Pando, F. 1997: Flora Mycologica Iberica, Vol. 2. Myxomycetes, I. Ceratiomyxales, Echinosteliales, Liceales, Trichales. - Cramer, Madrid - Berlin - Stuttgart. 323 pp.

Lakhanpal, T.N. \& Mukerji, K.G. 1976: Taxonomic studies on Indian myxomycetes I. The order Echinosteliales. - Norwegian J. Bot. 23: 107-111.

Martin, G.W. \& Alexopoulos, C.J. 1969: The myxomycetes. - Univ. Iowa Press, Iowa City. 560 pp., 41 pl.

McManus, M.A. 1961: Laboratory cultivation of Clastoderma debaryanum. - American J. Bot. 48: 884 888.

Meylan, C. 1914: Myxomycètes du Jura (Suite). - Bull. Soc. Bot. Genève II. 6: 86-90.

Mims, C. 1973: A light and electron microscope study of sporulation in the myxomycete Stemonitis virginiensis. - Protoplasma 77: 35-54.

Ross, I.K. 1957: Capillitium formation in the Stemonitaceae. - Mycologia 49: 809-819.

Ross, I.K. 1973: The Stemonitomycetidae, a new subclass of Myxomycetes. - Mycologia 65: 477-485.

Schnittler, M. \& Novozhilov, Y. 1998: Late-autumn myxomycetes of the Northern Ammergauer Alps. Nova Hedwigia 66: 205-222.

Schnittler, M., Stephenson, S.L. \& Novozhilov, Y.K. 2000: Ecology and world ditribution of Barbeyella minutissima (Myxomycetes). - Mycol. Res. 104 (in press).

Stephenson, S.L. 1983: Myxomycetes associated with southern Appalachian spruce-fir forests. - Proc. West Virginia Acad. Sci. 56: 118-124. 